\title{
Comparison of two analgesia protocols for the treatment of pediatric orthopedic emergencies
}

\author{
Andrea Barcelos ${ }^{1}$, Pedro Celiny Ramos Garcia ${ }^{2 *}$, Janete L. Portela ${ }^{3}$, Jefferson P. Piva ${ }^{4}$, João Pedro Tedesco Garcia ${ }^{5}$, \\ JoÃo Carlos B. Santana ${ }^{6}$

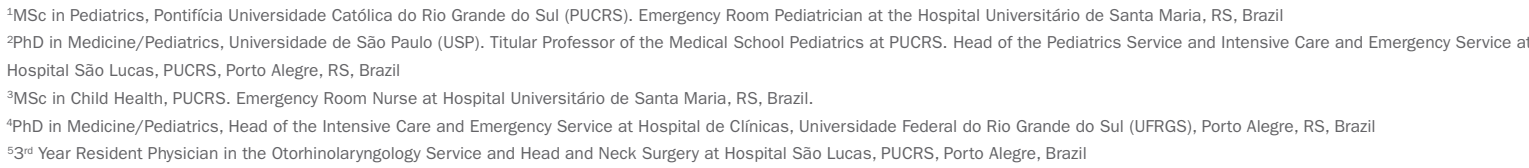

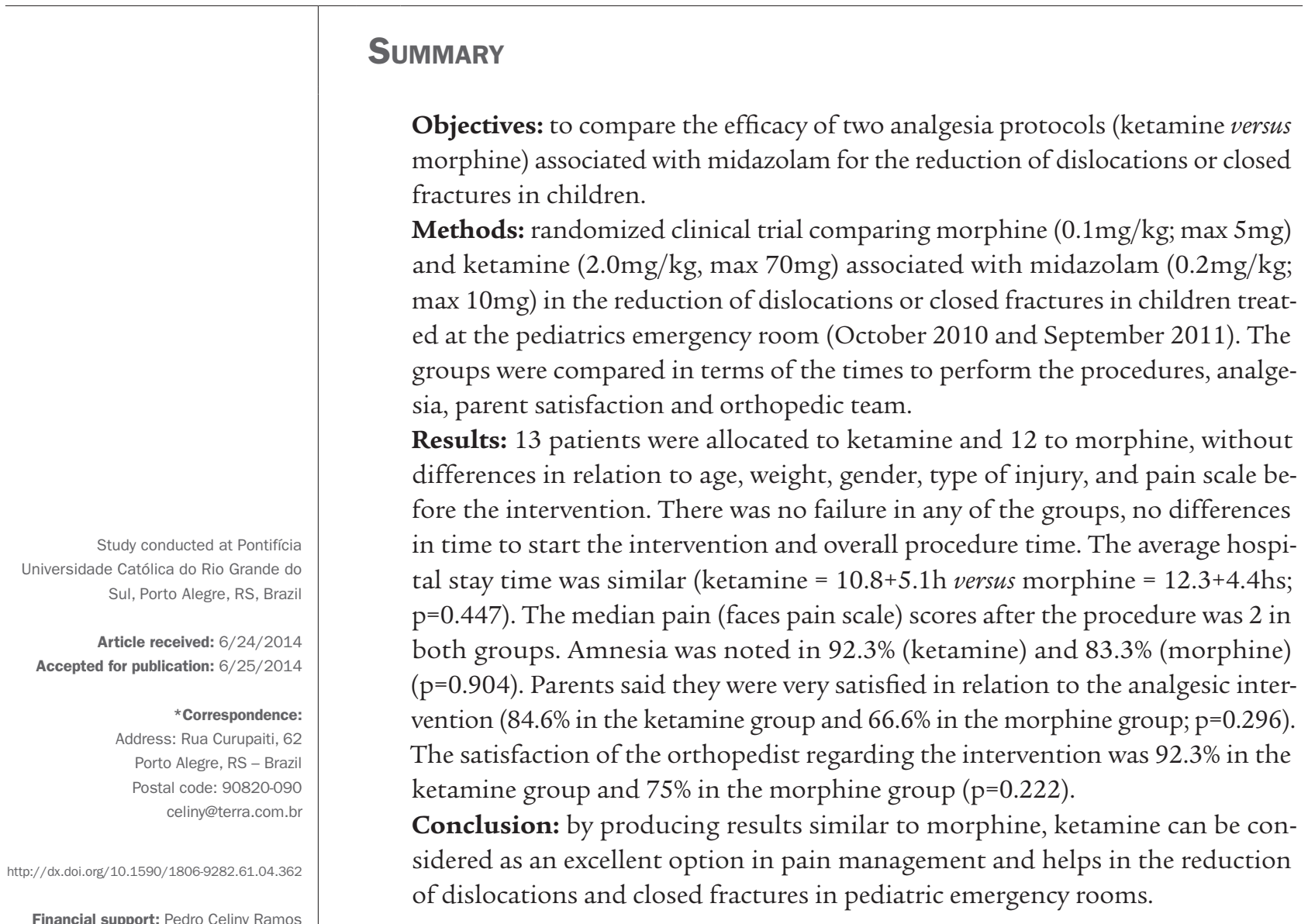

Financial support: Pedro Celiny Ramos Garcia holds a productivity scholarship in 1D Research from the CNPQ

\begin{abstract}
Objectives: to compare the efficacy of two analgesia protocols (ketamine versus morphine) associated with midazolam for the reduction of dislocations or closed dren.

Methods: randomized clinical trial comparing morphine $(0.1 \mathrm{mg} / \mathrm{kg}$; max $5 \mathrm{mg})$ and ketamine $(2.0 \mathrm{mg} / \mathrm{kg}$, max $70 \mathrm{mg})$ associated with midazolam $(0.2 \mathrm{mg} / \mathrm{kg}$; $\max 10 \mathrm{mg}$ ) in the reduction of dislocations or closed fractures in children treated at the pediatrics emergency room (October 2010 and September 2011). The groups were compared in terms of the times to perform the procedures, analgesia, parent satisfaction and orthopedic team.

Results: 13 patients were allocated to ketamine and 12 to morphine, without differences in relation to age, weight, gender, type of injury, and pain scale before the intervention. There was no failure in any of the groups, no differences tal stay time was similar (ketamine $=10.8+5.1 \mathrm{~h}$ versus morphine $=12.3+4.4 \mathrm{hs}$; $\mathrm{p}=0.447$ ). The median pain (faces pain scale) scores after the procedure was 2 in both groups. Amnesia was noted in $92.3 \%$ (ketamine) and $83.3 \%$ (morphine) $(\mathrm{p}=0.904)$. Parents said they were very satisfied in relation to the analgesic intervention (84.6\% in the ketamine group and $66.6 \%$ in the morphine group; $\mathrm{p}=0.296)$. The satisfaction of the orthopedist regarding the intervention was $92.3 \%$ in the ketamine group and $75 \%$ in the morphine group $(\mathrm{p}=0.222)$.

Conclusion: by producing results similar to morphine, ketamine can be conof dislocations and closed fractures in pediatric emergency rooms.
\end{abstract}

Keywords: fractures, bones, clinical protocols, pediatrics, analgesia.

\section{INTRODUCTION}

Traumatic injuries in childhood, especially dislocations and fractures are one of the main reasons for services in pediatric emergency units (PEU). Several studies have demonstrated that analgesia and sedation for reducing dislocations or closed fractures are conducted in an improper manner in pediatric emergency services. The ideal drug for sedation and analgesia used in these procedures should have a fast onset, be safe and easy to administer, in addition to causing amnesia and muscle relaxation. ${ }^{1-8}$
In pediatric emergency services, analgesia and sedation for the reduction of fractures and dislocations is often the responsibility of the emergency pediatrician. There are a wide variety of painkillers and sedatives to provide favorable conditions for carrying out the procedure safely. For this purpose, the pediatrician should know the main pharmacological characteristics, expected actions, adverse effects and, if necessary, how to antagonize them..$^{7-13}$

Opioids (morphine, fentanyl) are widely used due to their established efficacy and immediate availability.- ${ }^{2-510,12-15}$ 
There is evidence demonstrating safer treatment regimens than the combination of benzodiazepines and an opiate. Ketamine is a potent dissociative analgesic which in usual doses does not cause respiratory depression or hemodynamic instability. Due to its efficacy and limited adverse effects, it has become the drug of choice for many pediatric procedures. However, there are few well-designed, controlled and randomized clinical trials that have tested ketamine specifically in orthopedic emergencies. ${ }^{1,2,4-19}$

This study aims to compare the efficacy of two analgesia protocols (ketamine versus morphine) associated with midazolam for the reduction of dislocations or closed fractures in children treated at a reference pediatric emergency unit (PEU).

\section{Methods}

The authors conducted a randomized clinical study comparing two analgesia protocols in orthopedic emergencies in the pediatric emergency service of Hospital Universitário de Santa Maria (SEP-HUSM). The HUSM is a public general hospital linked to the Universidade Federal de Santa Maria (UFSM), Brazil. It is the largest public hospital in the state of Rio Grande do Sul, with 311 beds, and it is a regional reference center for 46 municipalities. At the SEP-HUSM about 1,140 children aged from birth to 14 years are treated.

Between October 2010 and September 2011, all patients admitted between Monday and Friday at the SEPHUSM, aged 3 years to 14 years, with dislocation or closed fracture that required orthopedic reduction maneuvers were included in the study. The study excluded patients with: (a) class III or higher of the American Society of Anesthesiologists (ASA III or above) (b) fractures for more than 24 hours (c) allergies or (d) contraindication to any medication used in the study and (e) parent or guardians who did not consent to participate in the study.

\section{Protocol}

Patients were selected consecutively and allocated randomly to receive analgesia with ketamine or morphine associated with midazolam. Randomization was conducted in blocks of ten (each manila envelope contained 5 papers from the ketamine group and 5 from the morphine group). Immediately after admission, the nurse responsible performed the draw, informed the pediatrician on duty of the results and prepared the medications according to the predefined doses.

Sedation, analgesia and management of complications were under the responsibility of the emergency pediatrician and the reduction procedure was performed by the orthopedic physician. To induce sedation, all patients received intravenous midazolam $(0.2 \mathrm{mg} / \mathrm{kg}$ up to a maximum dose of $10 \mathrm{mg}$ ) without additional doses. According to the draw performed by the nurse, one group received morphine $0.1 \mathrm{mg} / \mathrm{kg}$ intravenously, followed by increments of $0.05 \mathrm{mg} / \mathrm{kg}$ (at the physician's discretion) up to a maximum dose of $5 \mathrm{mg}$. The other group received ketamine $2 \mathrm{mg} / \mathrm{kg}$ intravenously up to a maximum dose of $70 \mathrm{mg}$, without additional doses. ${ }^{16}$ All patients were monitored according to the sedation and analgesia routines, including measurements of vital signs at the beginning, every 5 minutes and at the end of the procedure.

The SEP-HUSM nurse was responsible for the monitoring and follow-up of each patient during the procedure, recording adverse events. The faces pain scale was used to classify pain. ${ }^{6}$ To assess parental and orthopedist satisfaction after the procedure, the authors used the 5 point Likert scale (1: very pleased to 5 : very dissatisfied). ${ }^{7}$

\section{Assessments}

For comparison between both analgesia groups, the outcomes considered were time to start the intervention, duration of the procedure, the total time of the procedure, the child's cooperation, parental satisfaction and the satisfaction of the surgeon responsible for procedure. The groups were also compared in relation to the occurrence of adverse events related to the medication.

The time to start the intervention was defined as the time in minutes between the administration of drugs until the orthopedic physician considered that there was suitable sedation/analgesia. The duration of the procedure was established as the time in minutes from the beginning of the procedure until the splint or plaster was placed. The total time (intervention and procedure) was defined as the time in minutes between the administration of the drugs and the end of the placement of the splint or plaster. The procedure was considered successful if the patient did not need further reduction in the operating room. In the case of multiple reduction attempts only, the first attempt was included in the study.

Demographic data, medication doses, fasting time, time for the start of the intervention, procedure duration and duration of hospitalization were recorded. Before sedation and analgesia, and after the reduction procedure, the patient was assessed by the nurse using the faces pain scale. At the end of the procedure, a Likert scale was applied to assess parental and orthopedist satisfaction in relation to the procedure. Before discharge, the child was questioned as to whether they remembered the procedure 
by answering yes or no. The recommended criteria for hospital discharge were stable and satisfactory cardiovascular function, patent airways and ease in waking up the patient, able to talk and sit unaided and with protective reflexes intact. The study was approved by the Research Ethics Committee at the UFSM (CAAE - 0225.0.243.000$10)$, requiring parents or guardians to sign an informed consent form after being suitably informed in order to participate in the study.

\section{Statistical analysis}

The categorical variables were expressed as percentages and compared using the chi-square test or Fisher's exact test. Continuous variables with normal distribution, were expressed using the mean with standard deviation, and compared using the Student's t-test. Variables without a normal distribution were expressed as a median with the respective interquartile range (IQ 25\%-75\%) and compared using the Mann-Whitney U test. The data were transcribed into an Excel spreadsheet for Windows (Microsoft Office) and analyzed using SPSS software version 16.0.

\section{Results}

During the study period, 79 patients attended the SEP-HUSM due to an osteoarticular injury. Among these, 54 (68\%) did not present criteria for inclusion in the sample (three under the age of three years, 18 required surgical treatment, 10 had open fractures and 23 were treated on weekends). 25 patients with a closed fracture or dislocation remained, who required intravenous sedation and analgesia to perform a closed reduction, with 13 patients allocated to ketamine and 12 to the morphine group. There were no differences between the groups with respect to age, weight, gender, fasting time, type of injury, vital signs on arrival to the emergency and pain scale before the intervention (Table 1).

TABLE 1 General characteristics and vital signs of the two analgesia groups before the start of orthopedic reduction procedures.

\begin{tabular}{llll} 
& $\begin{array}{l}\text { Ketamine } \\
(\mathbf{n = 1 3})\end{array}$ & $\begin{array}{l}\text { Morphine } \\
(\mathbf{n = 1 2})\end{array}$ & P \\
\hline Age (months) & $90.7 \pm 34.1$ & $102.1 \pm 48.5$ & $0.501^{\mathrm{a}}$ \\
Median & $95.9(52.6-125.9)$ & $105.5(57.0-141.7)$ & \\
\hline Weight $(\mathrm{kg})$ & $27.5 \pm 13.6$ & $30.4 \pm 14.3$ & $0.461^{\mathrm{b}}$ \\
Median & $25.0(17.0-31.5)$ & $28.0(17.7-33.8)$ & \\
\hline Male N $(\%)$ & $11(57.9)$ & $8(42.1)$ & $0.294^{\mathrm{c}}$ \\
\hline Fasting time & $6(5.0-7.5)$ & $6(4.0-7.6)$ & $0.696^{\mathrm{b}}$ \\
(hours) & & & \\
\hline
\end{tabular}

\begin{tabular}{|c|c|c|c|}
\hline & $\begin{array}{l}\text { Ketamine } \\
(n=13)\end{array}$ & $\begin{array}{l}\text { Morphine } \\
(n=12)\end{array}$ & $\mathbf{p}$ \\
\hline Type of injury & & & $0.901^{c}$ \\
\hline Fracture & 12 & 11 & \\
\hline Dislocation & 1 & 1 & \\
\hline Heart rate (bpm) & $112.5 \pm 54.5$ & $134.0 \pm 43.0$ & $0.113^{b}$ \\
\hline $\begin{array}{l}\text { Respiratory rate } \\
(\mathrm{mrm})\end{array}$ & $25.8 \pm 4.3$ & $26.8 \pm 4.0$ & $0.611^{\mathrm{a}}$ \\
\hline $\begin{array}{l}\text { Oxygen } \\
\text { saturation (\%) }\end{array}$ & $99.0 \pm 1.0$ & $98.0 \pm 2.0$ & $0.386^{\mathrm{b}}$ \\
\hline $\begin{array}{l}\text { Diastolic blood } \\
\text { pressure } \\
(\mathrm{mmHg})\end{array}$ & $69.0 \pm 20.0$ & $76.0 \pm 7.0$ & $0.218^{b}$ \\
\hline
\end{tabular}

The averages are expressed with the respective standard deviation (DP), while the medians are accompanied by the respective ranges (minimum and maximum value) and absolute values $(\mathrm{N})$ accompanied by the percentage (\%)

a Continuous variables with normal distribution compared using Student's t-test.

${ }^{b}$ Continuous variables without normal distribution compared using Mann-Whitney $\mathrm{U}$ test.

${ }^{\mathrm{c} C}$ Categorical variables compared using chi-square or Fisher exact tests.

Both protocols were shown to be effective, with no treatment failures in either group. The authors did not observe significant differences in the time to begin the intervention, or in the total procedure time between the two groups (Table 2). However, the duration of the intervention was significantly lower in the morphine group in relation to the ketamine group (median of 3 versus 5 minutes; $\mathrm{p}<0.027)$.

\section{TABLE 2 Comparison between analgesia groups in} relation to the time to start the intervention, procedure duration and total time (intervention and procedure).

\begin{tabular}{|c|c|c|c|}
\hline & $\begin{array}{l}\text { Ketamine } \\
(n=13)\end{array}$ & $\begin{array}{l}\text { Morphine } \\
(n=12)\end{array}$ & $\mathbf{p}$ \\
\hline Time to start intervention (min.) & $3(1.5-5.0)$ & $2.5(2.0-5.0)$ & $0.867^{b}$ \\
\hline Procedure duration time (min.) & $5(4.0-15.0)$ & $3(1.0-5.0)$ & $0.027^{b}$ \\
\hline $\begin{array}{l}\text { Total time - intervention and } \\
\text { procedure (min.) }\end{array}$ & $10(6.0-18.5)$ & $6(3.2-9.5)$ & $0.063^{b}$ \\
\hline
\end{tabular}

Based on Table 3, it is clear that the average time of hospitalization was similar between the two groups (ketamine $=10.8 \pm 5.2$ hours versus morphine $=12.3 \pm 4.4$ hours; $\mathrm{p}=0.447$ ). The median pain analyzed using the faces pain scale following the procedure was 2 on both groups. Applying the delta test, no statistically significant difference was found in the presence of pain at the end of the procedure. Most of the children did not remember performing the proce- 
dure in both types of analgesia (ketamine $=92.3 \%$ versus morphine $=83.3 \% ; \mathrm{p}=0.904$ ).

Adverse effects related to use of the drugs were similar in both groups. No patient suffered apnea, laryngospasm, tachycardia, or hypotension, neither was the use of antagonists (flumazenil or naloxone) required.

\section{TABLE 3 Comparison between the two groups of} analgesia in relation to pain scale, satisfaction of parents and orthopedist, amnesia in relation to the procedure, adverse reactions to the analgesic and hospital stay.

\begin{tabular}{llll} 
& $\begin{array}{l}\text { Ketamine } \\
(\mathbf{n = 1 3 )}\end{array}$ & $\begin{array}{l}\text { Morphine } \\
(\mathbf{n = 1 2 )}\end{array}$ & $\mathbf{P}$ \\
\hline Hospitalization time (hours) & $10.8 \pm 5.2$ & $12.3 \pm 4.4$ & $0.447^{\mathrm{a}}$ \\
\hline Pain scale (after procedure) & $2(0.0-4.0)$ & $2(0.0-6.0)$ & $0.909^{\mathrm{b}}$ \\
\hline Pain delta (after procedure) & $4(0.0-6.0)$ & $4(-1.5-6.0)$ & $0.868^{\mathrm{b}}$ \\
\hline Amnesia of the procedure & $12(92.3)$ & $10(83.3)$ & $0.904^{\mathrm{c}}$
\end{tabular}

(yes) \%

\begin{tabular}{llll}
\hline Vomiting (yes) \% & $1(7.7)$ & $3(25.0)$ & $0.238^{c}$ \\
\hline Agitation/hallucination (yes) \% & $2(15.4)$ & $4(33.3)$ & $0.294^{c}$ \\
\hline $\begin{array}{l}\text { Fall in oxygen saturation (yes) } \\
\%\end{array}$ & $1(7.7)$ & $3(25.0)$ & $0.238^{c}$
\end{tabular}

\begin{tabular}{llll}
\hline Parental satisfaction & $11(84.6)$ & $8(66.6)$ & $0.296^{c}$
\end{tabular}

(very satisfied) \%

$\begin{array}{llll}\text { Orthopedist satisfaction } & 12(92.3) & 9(75) & 0.222^{c}\end{array}$

(very satisfied) \%

Key to tables: The measurements are expressed with the respective standard deviation ( SD) while the medians are present with their respective ranges (minimum and maximum value) and absolute values $(\mathrm{N})$ accompanied by the percentage $(\%)$.

${ }^{a}$ Continuous variables with normal distribution compared using Student's t-test.

${ }^{b}$ Continuous variables without normal distribution compared using Mann-Whitney $\mathrm{U}$ test.

'Categorical variables compared using chi-square or Fisher exact tests.

Parents said they were very satisfied in relation to the analgesic intervention in $84.6 \%$ of patients that used ketamine, and in $66.6 \%$ that used morphine ( $p=0.296$ ). In the same manner, the maximum satisfaction of the orthopedist regarding the intervention was $92.3 \%$ in the ketamine group and $75 \%$ in the morphine group $(\mathrm{p}=0.222)$.

\section{Discussion}

Sedoanalgesia is an essential procedure for closed orthopedic reduction at PEUs. The present study demonstrated that analgesia with ketamine for closed reduction of fractures and dislocations showed similar clinical results to those obtained with morphine. Both parents and orthopedic teams expressed satisfaction with both medications. Therefore, by adopting morphine by default in this type of procedure, it may be concluded that ketamine had the same degree of effectiveness, alongside its known safety and low incidence of side effects.
Sedation and analgesia in PEUs should be directed according to the effectiveness, safety and cost, and should be performed by physicians experienced in airway management and treatment of cardio-respiratory complications, familiar with the pharmacodynamics and pharmacokinetics of the drugs used., ${ }^{1,8,9,17,19-21}$ Sedation and analgesia in these situations should be performed in a service that has support from nursing staff for the monitoring of vital signs and continuous clinical observation of the patient, in addition to appropriate equipment for airway management and cardiopulmonary resuscitation, especially heart monitors and/or continuous pulse oximetry. $8,22,23$

In this study, both analgesia protocols had favorable outcomes, notably in terms of pain control, start time of the intervention by the orthopedist, the total procedure time, success in reducing the fracture and the occurrence of amnesia, in agreement with other studies. 1,2,-7, 12-17,23,24 The procedure duration time in the morphine group was slightly lower than in the ketamine group, a result also found in a similar study. ${ }^{9,10}$ The sedation and analgesia schemes most commonly used in PEU involve the association of an opioid (morphine or fentanyl) with midazolam or the administration of ketamine with or without midazolam. ${ }^{24-26}$ Morphine remains the most widely used drug in severe and chronic pain, however, fentanyl has been employed in more time-consuming procedures due to its faster start and peak of action and more prolonged effect. Ketamine is a dissociative agent, blocking opioid receptors, which rapidly induces sedation, profound analgesia, immobility and cataplegia, preserving spontaneous respiration. ${ }^{16}$ Havel et al. monitored 89 children who received two different analgesia schemes for fracture reduction (midazolam/morphine vs. propofol/morphine) and found that both groups had similar efficiencies and insignificant adverse events. ${ }^{24}$ Godambe et al. analyzed analgesia used on 113 children undergoing orthopedic procedures and found that both protocols (ketamine/midazolam $v$ s. propofol/fentanyl) had similar results for the relief of pain and anxiety, although the propofol/fentanyl group presented a shorter procedure time. ${ }^{2}$

In this study, the presence of hypoxemia was an unusual finding and there was significant difference between the groups who used ketamine or morphine. However, hypoxia is one of the adverse effects associated with the use of opioids cited most in the literature., ${ }^{2,50}$ Kennedy et al. observed that the group of patients using analgesia with fentanyl/midazolam had more hypoxemia $(25 \%$ vs. $6 \%$; $\mathrm{p}<0.001)$, requiring respiratory stimulation $(12 \% v s .1 \%$; $\mathrm{p}<0.01)$ and oxygen therapy $(20 \%$ vs. $10 \%$; $\mathrm{p}<0.05)$ than 
those who received ketamine/midazolamm. ${ }^{5}$ Ketamine administered by intravenous or intramuscular routes, even as a single drug, has been indicated as a safe and effective alternative for rapid analgesia. ${ }^{6,10,27,28}$ In a systematic review of randomized trials of analgesia and sedation for reduction of fractures in children at a PEU, ketamine/ midazolam proved to be more effective as an analgesic and had fewer adverse effects than combinations of fentanyl/midazolam or propofol/midazolam. . $^{1,4,5,15,25}$

When the level of satisfaction of parents and orthopedists were analyzed with analgesia for the orthopedic procedure, it was found that levels were quite high. Satisfaction was similar regardless of analgesic used, whether morphine or ketamine, a fact also described in other studies.,29

\section{Conclusion}

Considering pain control, shorter start time of the intervention by the orthopedist, lower total procedure time, success in reduction of the fracture, the presence of amnesia and low incidence of adverse effects, especially respiratory disorders, ketamine was shown to be a safe and effective analgesic for use in orthopedic emergencies. As these results were equivalent to those found in the group using morphine, a widely used analgesic, ketamine can be considered as an excellent option in pain management, and helps in the reduction of dislocations and closed fractures in pediatric emergency rooms.

\section{Resumo}

Comparação de dois protocolos de analgesia para tratamento de emergências ortopédicas pediátricas

Objetivo: comparar a eficácia de dois protocolos de analgesia (cetamina versus morfina) associados ao midazolam para a redução de luxações ou fraturas fechadas em crianças.

Métodos: ensaio clínico randomizado comparando morfina $(0,1 \mathrm{mg} / \mathrm{kg}$; máx. $5 \mathrm{mg})$ e cetamina $(2,0 \mathrm{mg} / \mathrm{kg}$; máx. $70 \mathrm{mg})$ associados a midazolam $(0,2 \mathrm{mg} / \mathrm{kg}$; máx. $10 \mathrm{mg})$ na redução de luxações ou fraturas fechadas em crianças atendidas em emergência pediátrica, no período de outubro de 2010 a setembro de 2011. Os grupos foram comparados segundo os seguintes indicadores: tempo para realizar os procedimentos, analgesia, satisfação de pais e da equipe ortopédica.

Resultados: treze pacientes foram alocados para cetamina e 12 para morfina, sem diferenças em relação a idade, peso, gênero, tipo de lesão e escala da dor antes da intervenção. Não houve falha em nenhum dos grupos, sem di- ferenças no tempo para iniciar a intervenção e no tempo total de procedimento. O tempo médio de hospitalização foi similar (cetamina $=10,8 \pm 5,1$ h versus morfina $=12,3 \pm 4,4$ $\mathrm{h} ; \mathrm{p}=0,447)$. A mediana de dor (escala de faces da dor) após o procedimento foi de $2 \mathrm{em}$ ambos os grupos. Amnésia foi observada em 92,3\% (cetamina) e 83,3\% (morfina) ( $p=0,904$ ). Os pais declararam estar muito satisfeitos em relação à intervenção analgésica (84,6\% no grupo cetamina e $66,6 \%$ no grupo morfina; $p=0,296$ ). A satisfação do ortopedista em relação à intervenção foi de $92,3 \%$ no grupo cetamina e $75 \%$ no grupo da morfina $(\mathrm{p}=0,222)$.

Conclusão: a cetamina, ao apresentar resultados semelhantes à morfina, pode ser considerada uma excelente opção no manejo da dor e no auxílio da redução de luxações e fraturas fechadas em salas de emergência pediátrica.

Palavras-chave: fraturas ósseas, protocolos clínicos, pediatria, analgesia.

\section{References}

1. Migita RT, Klein EJ, Garrison MM. Sedation and analgesia for pediatric fracture reduction in the emergency department: a systematic review. Arch Pediatr Adolesc Med. 2006; 160(1):46-51.

2. Godambe SA, Elliot V, Matheny D, Pershad J. Comparison of propofol/ fentanyl versus ketamine/midazolam for brief orthopedic procedural sedation in a pediatric emergency department. Pediatrics. 2003; 112(1 Pt 1):116-23.

3. Waterman GD Jr, Leder MS, Cohen DM. Adverse events in pediatric ketamine sedation with or without morphine pretreatment. Pediatr Emerg Care. 2006; 22(6):408-11

4. Lee-Jayaram JJ, Green A, Siembieda J, Gracely EJ, Mull CC, Quintana E, et al. Ketamine/midazolam versus etomidate/fentanyl: procedural sedation for pediatric orthopedic reductions. Pediatr Emerg Care. 2010; 26(6):408-12.

5. Kennedy RM, Porter FL, Miller JP, Jaffe DM. Comparison of fentanyl/ midazolam with ketamine/midazolam for pediatric orthopedic emergencies. Pediatrics. 1998; 102(4 Pt 1):956-63.

6. Roback MG, Wathen JE, MacKenzie T, Bajaj L. A randomized, controlled trial of i.v. versus i.m. ketamine for sedation of pediatric patients receiving emergency department orthopedic procedures. Ann Emerg Med. 2006; 48(5):605-12.

7. McCarty EC, Mencio GA, Walker LA, Green NE. Ketamine sedation for the reduction of childrens fractures in the emergency department. J Bone Joint Surg Am. 2000; 82-A(7):912-8

8. Kennedy RM, Luhmann JD, Luhmann SJ. Emergency department management of pain and anxiety related to orthopedic fracture care: a guide to analgesic techniques and procedural sedation in children. Paediatr Drugs. 2004; 6(1):11-31.

9. Shavit I, Hershman E. Management of children undergoing painful procedures in the emergency department by non-anesthesiologists. Isr Med Assoc J. 2004; 6(6):350-5.

10. Pitetti RD, Singh S, Pierce MC. Safe and efficacious use of procedural sedation and analgesia by nonanesthesiologists in a pediatric emergency department. Arch Pediatr Adolesc Med. 2003; 157(11):1090-6.

11. Roback MG, Bajaj L, Wathen JE, Bothner J. Preprocedural fasting and adverse events in procedural sedation and analgesia in a pediatric emergency department: are they related? Ann Emerg Med. 2004; 44(5):454-9.

12. Atkinson P, Chesters A, Heinz P. Pain management and sedation for children in the emergency department. BMJ. 2009; 339:b4234.

13. Sahyoun C, Krauss. Clinical implications of pharmacokinetics and pharmacodynamics of procedural sedation agents in children. Curr Opin Pediatr. 2012; 24(2):225-32.

14. Carstensen M, Moller AM. Adding ketamine to morphine for intravenous patient-controlled analgesia for acute postoperative pain: a qualitative review of randomized trials. Br J Anaesth. 2010; 104(4):401-6. 
15. McQueen A, Wright RO, Kido MM, Kaye E, Krauss B. Procedural sedation and analgesia outcomes in children after discharge from the emergency department: ketamine versus fentanyl/midazolam. Ann Emerg Med. 2009; 54(2):191-7.

16. Green SM, Roback MG, Kennedy RM, Krauss B. Clinical practice guideline for emergency department ketamine dissociative sedation: 2011 update. Ann Emerg Med. 2011; 57(5):449-61.

17. Krauss B, Green SM. Sedation and analgesia for procedures in children. N Engl J Med. 2000; 342(13):938-45.

18. Melendez E, Bachur R. Serious adverse events during procedural sedation with ketamine. Pediatr Emerg Care. 2009; 25(5):325-8

19. Green SM, Roback MG, Krauss B, Brown L, McGlone RG, Agrawal D, et al.; Emergency Department Ketamine Meta-Analysis Study Group. Predictors of emesis and recovery agitation with emergency department ketamine sedation: an individual-patient data meta-analysis of 8,282 children. Ann Emerg Med. 2009; 54(2):171-80.

20. Mace SE, Brown LA, Francis L, Godwin SA, Hahn SA, Howard PK, et al.; EMSC Panel (Writing Committee) on Critical Issues in the Sedation of Pediatric Patients in the Emergency. Clinical policy: critical issues in the sedation of pediatric patients in the emergency department. Ann Emerg Med. 2008; 51(4):378-99.

21. Krauss B, Green SM. Training and credentialing in procedural sedation and analgesia in children: lessons from the United States model. Paediatr Anaesth. $2008 ; 18(1): 30-5$
22. Krauss B, Green SM. Procedural sedation and analgesia in children. Lancet. 2006; 367(9512):766-80.

23. Doyle L, Colletti JE. Pediatric procedural sedation and analgesia. Pediatr Clin North Am. 2006; 53(2):279-92.

24. Havel CJ Jr, Strait RT, Hennes H. A clinical trial of propofol vs midazolam for procedural sedation in a pediatric emergency department. Acad Emerg Med. 1999; 6(10):989-97.

25. Wathen JE, Roback MG, Mackenzie T, Bothner JP. Does midazolam alter the clinical effects of intravenous ketamine sedation in children? A doubleblind, randomized, controlled, emergency department trial. Ann Emerg Med. 2000; 36(6):579-88.

26. Evans D, Turnham L, Barbour K, Kobe J, Wilson L, Vandebeek C, et al. Intravenous ketamine sedation for painful oncology procedures. Paediatr Anaesth. 2005; 15(2):131-8.

27. Green SM, Krauss B. Clinical practice guideline for emergency department ketamine dissociative sedation in children. Ann Emerg Med. 2004; 44(5):460-71.

28. Taylor DM, Bell A, Holdgate A, MacBean C, Huynh T, Thom O, et al. Risk factors for sedation-related events during procedural sedation in the emergency department. Emerg Med Australas. 2011;23(4):466-73.

29. O'Rourke D. The measurement of pain in infants, children, and adolescents: from policy to practice. Phys Ther. 2004; 84(6):560-70. 